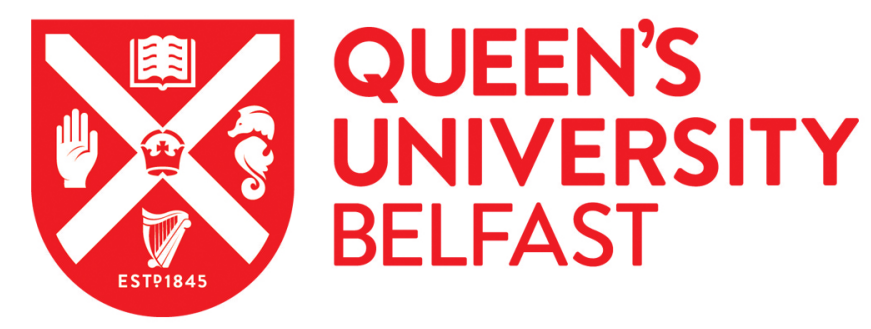

\title{
Long-term application of animal slurries to grassland alters soil cation balance
}

Murphy, P. N. C., Stevens, R. J., \& Christie, P. (2005). Long-term application of animal slurries to grassland alters soil cation balance. Soil Use and Management, 21(2), 240-244. https://doi.org/10.1079/SUM2005317

Published in:

Soil Use and Management

Queen's University Belfast - Research Portal:

Link to publication record in Queen's University Belfast Research Portal

\section{General rights}

Copyright for the publications made accessible via the Queen's University Belfast Research Portal is retained by the author(s) and / or other copyright owners and it is a condition of accessing these publications that users recognise and abide by the legal requirements associated with these rights.

Take down policy

The Research Portal is Queen's institutional repository that provides access to Queen's research output. Every effort has been made to ensure that content in the Research Portal does not infringe any person's rights, or applicable UK laws. If you discover content in the Research Portal that you believe breaches copyright or violates any law, please contact openaccess@qub.ac.uk. 


\title{
Long-term application of animal slurries to grassland alters soil cation balance
}

\author{
P.N.C. Murphy ${ }^{1}$, R.J. Stevens ${ }^{1,2} \&$ P. Christie ${ }^{1,2, *}$
}

\begin{abstract}
Soil samples from a 32-year grassland field experiment were taken from 0-5, 5-10, and $10-15 \mathrm{~cm}$ soil depths in February 2002. Plots received annual treatments of unamended control, mineral fertilizer, three rates of pig slurry and three rates of cow slurry, each with six replicates. Samples were analysed for cation exchange capacity (CEC), exchangeable cations $\left(\mathrm{Na}^{+}, \mathrm{K}^{+}, \mathrm{Ca}^{2+}, \mathrm{Mg}^{2+}\right), \mathrm{pH}$ and Olsen P. Exchangeable sodium percentage (ESP) was calculated as a sodicity indicator. Mean ESP was generally greater for slurry treatments than the control, with a trend of increasing ESP with application rate. This was particularly marked for cow slurry. At $0-5 \mathrm{~cm}$ depth ESP increased from 1.18 in the control to 1.75 at the highest rate of pig slurry and 5.60 at the highest rate of cow slurry. Similar trends were shown for CEC, exchangeable $\mathrm{Na}^{+}$, $\mathrm{K}^{+}$and $\mathrm{Mg}^{2+}, \mathrm{Ca}^{2+}$ and Olsen P. The build-up of soil $\mathrm{P}$ due to slurry applications, together with this combination of physical and chemical factors, may increase the risk of $P$ loss to surface waters, particularly from soils receiving high rates of cow slurry.
\end{abstract}

Keywords: Phosphorus, sodicity, cation exchange capacity, phosphorus loss, infiltration, animal slurry

\section{INTRODUCTION}

$\mathrm{T}$ he application of animal slurry to grassland is a common agricultural practice. Slurry is applied to farmland not only as a source of plant nutrients, but also as a means of recycling organic manures produced on the farm. Organic manure application alters both chemical and physical properties of soil (Shaviv et al. 1986; Christie 1987; Haynes \& Naidu 1998; Hao \& Chang 2002), which has implications for aspects of the agro-environmental system such as plant nutrient supply and nutrient loss to surface waters. Soil sodicity may be increased, which is known to damage soil structure and alter soil hydraulic properties (Shainberg \& Letey 1984; Sumner 1993). Much work has highlighted the risk of nutrient loss, particularly phosphorus $(\mathrm{P})$, from soils receiving organic fertilizers (McGechan 2001; Van Vliet et al. 2002) and this has been identified as a major contributor to the eutrophication of surface water bodies. Diffuse source pollution of surface waters by $\mathrm{P}$ from farming activities is a major environmental problem in Ireland (Foy et al. 1995; Heaney et al. 2001). Long-term slurry applications to grassland increased soil $\mathrm{P}$ status considerably and in proportion to application rates (Anderson \& Wu 2001). These increased soil P levels were related to increased molybdate reactive $\mathrm{P}$ in the soil solution beneath the plots. The present study followed on

${ }^{1}$ Department of Agricultural and Environmental Science, Queen's University Belfast, Newforge Lane, Belfast BT9 5PX, UK. ${ }^{2}$ Agriculture, Food and Environmental Science Division, Department of Agriculture and Rural Development, Newforge Lane, Belfast BT9 5PX, UK.

*Corresponding author. Fax: + 44 (0)28 90255005.

E-mail: peter.christie@dardni.gov.uk from Anderson \& Wu (2001) and tested whether long-term slurry application alters soil cation balance. The implications this may have for $\mathrm{P}$ loss to surface waters from these soils are assessed.

\section{MATERIALS AND METHODS}

Forty-eight plots, each $29.75 \mathrm{~m}^{2}$ in area, were established in 1970 on a clay loam $(0-30 \mathrm{~cm})$ grassland soil at Hillsborough, Co. Down in northeast Ireland (Christie 1987). The soil is a Dystric Cambisol developed on glacial till overlying Silurian shales and greywackes. The soil has an organic matter content of $4.25 \%$ and its hydrogeological class number within HOST (Hydrology of Soil Types) is 18 sensu Boorman et al. (1995). The site is considered typical of a large area of grassland in Northern Ireland. The plots were laid out on an established perennial ryegrass sward approximately 120 metres above sea level. Eight treatments with six replicates each were distributed as a randomized block. The treatments were:

- control with no nutrient amendment (CTRL),

- mineral fertilizer at $200 \mathrm{~kg} \mathrm{~N}, 32 \mathrm{~kg} \mathrm{P}$ and $160 \mathrm{~kg} \mathrm{~K} \mathrm{ha}^{-1}$ $\mathrm{yr}^{-1}$ (NPK),

- pig slurry at $50 \mathrm{~m}^{3} \mathrm{ha}^{-1} \mathrm{yr}^{-1}$ (LP),

- pig slurry at $100 \mathrm{~m}^{3} \mathrm{ha}^{-1} \mathrm{yr}^{-1}$ (MP),

- pig slurry at $200 \mathrm{~m}^{3} \mathrm{ha}^{-1} \mathrm{yr}^{-1}$ (HP),

- cow slurry at $50 \mathrm{~m}^{3} \mathrm{ha}^{-1} \mathrm{yr}^{-1}$ (LC),

- cow slurry at $100 \mathrm{~m}^{3} \mathrm{ha}^{-1} \mathrm{yr}^{-1}$ (MC) and

- cow slurry at $200 \mathrm{~m}^{3} \mathrm{ha}^{-1} \mathrm{yr}^{-1}$ (HC).

For further details, see Christie (1987). In conventional farming practice, farmers would usually be advised to make 
slurry application rates between 50 and $100 \mathrm{~m}^{3} \mathrm{ha}^{-1} \mathrm{yr}^{-1}$. The highest application rate was included in the experiment to test extreme conditions. No lime was applied to the plots during the first 20 years of the experiment and soil $\mathrm{pH}$ declined to varying extents in the different treatments (Christie 1987). The exceptions were the MC and HC slurry treatments in some plots in which the slurry acted as an effective liming material that maintained soil $\mathrm{pH}>6$. In November 1990 and October 1994 lime was applied to all of the acidified plots to raise their surface $\mathrm{pH}$ to 6 .

Composite soil samples were taken to a depth of $15 \mathrm{~cm}$ using half-corer augers. These cores were sectioned to depths of $0-5,5-10$ and $10-15 \mathrm{~cm}$. Samples were airdried and ground to pass a $2 \mathrm{~mm}$ sieve. Soil $\mathrm{pH}$ was measured in water with a glass electrode at a $1: 2.5$ soilwater ratio (MAFF 1986). Phosphorus extractable by sodium bicarbonate (Olsen P) was determined by a modification (MAFF 1986) of the method of Olsen et al. (1957). Exchangeable $\mathrm{Na}^{+}, \mathrm{K}^{+}, \mathrm{Ca}^{2+}$ and $\mathrm{Mg}^{2+}$ were determined by commonly used methods (MAFF 1986), except that ammonium acetate replaced ammonium nitrate. $\mathrm{K}^{+}$and $\mathrm{Na}^{+}$were measured with a Corning 410 flame photometer and $\mathrm{Ca}^{2+}$ and $\mathrm{Mg}^{2+}$ with a Perkin Elmer 2380 atomic absorption spectrophotometer. Cation exchange capacity was determined by compulsive exchange of $\mathrm{Mg}^{2+}$ on to a Ba-saturated soil sample (Avery \& Bascomb 1974). Exchangeable sodium percentage (ESP) was used as a sodicity indicator and calculated as:

$$
\mathrm{ESP}=100\left(\mathrm{Na}_{\mathrm{ex}} / \mathrm{CEC}\right)
$$

where $\mathrm{Na}_{\mathrm{ex}}=$ exchangeable $\mathrm{Na}^{+}\left(\mathrm{cmol}_{\mathrm{c}} \mathrm{kg}^{-1}\right)$ and $\mathrm{CEC}=$ cation exchange capacity $\left(\mathrm{cmol}_{\mathrm{c}} \mathrm{kg}^{-1}\right)$.

Means and standard errors were calculated and the significance of treatment effects was tested by ANOVA with repeated measures using the GENSTAT statistical package. Repeated measures analysis was used because values over depth were not statistically independent.

\section{RESULTS AND DISCUSSION}

Slurry treatments increased CEC from a mean of $22.8 \mathrm{cmol}_{\mathrm{C}} \mathrm{kg}^{-1}$ in the CTRL treatment to $24.2 \mathrm{cmol}_{\mathrm{c}} \mathrm{kg}^{-1}$ at the medium slurry rate and $27.0 \mathrm{cmol}_{\mathrm{c}} \mathrm{kg}^{-1}$ at the high slurry rate. Slurry application presumably increased soil organic matter (SOM) and hence CEC. Mean values for exchangeable $\mathrm{Ca}^{2+}, \mathrm{Mg}^{2+}, \mathrm{Na}^{+}$and $\mathrm{K}^{+}$at each depth are shown in Table 1. Thirty-two years of slurry applications have altered the exchangeable cation balance, although the interpretation of exchangeable $\mathrm{Ca}^{2+}$ values is confounded by the differential application of lime. Lime was applied in November 1990 and October 1994 to maintain soil $\mathrm{pH} \geq 6.0$ in the top $15 \mathrm{~cm}$, so all but one of the plots receiving the high-rate cow slurry treatment and all but two of the plots receiving the medium-rate cow slurry treatment were never limed because their $\mathrm{pH}$ was already greater than 6.0. The highest application rate of slurry tested was included in the experiment to investigate extreme conditions, and it could be argued that the effects of cow slurry applied at $200 \mathrm{~m}^{3} \mathrm{ha}^{-1} \mathrm{yr}^{-1}$ are only of academic interest. However, farmers may not always have closely followed advisory guidelines. For example, they may tend to spread more slurry on fields with good drainage characteristics. As a result, some fields may have received large application rates similar to the highest rate in our experiment. Some intensively managed farms may also apply slurry at higher than recommended rates because of limited land area for spreading.

All of the slurry treatments increased exchangeable $\mathrm{Mg}^{2+}$, the increase with cow slurry being greater than with pig slurry. On average over $0-15 \mathrm{~cm}$ soil depth within a slurry type, exchangeable $\mathrm{Mg}^{2+}$ increased linearly with rate of application (Figure 1). The HP and all cow slurry treatments increased exchangeable $\mathrm{K}^{+}$and $\mathrm{Na}^{+}$. On average over $0-15 \mathrm{~cm}$ soil depth exchangeable $\mathrm{Na}^{+}$and $\mathrm{K}^{+}$ increased linearly with application rate for cow slurry (Figure 2). Exchangeable cations decreased with depth for all treatments (Table 1).

Although we have emphasized long-term slurry application, it should be noted that these changes in soil cation balance might occur over a much shorter term. Further work using archived soil samples from the site would be required to assess whether this had occurred.

The NPK treatment had no significant effect on ESP (Table 1). The effect of slurry treatments on ESP, averaged over all depths, is shown in Figure 3. For pig slurry, only the HP treatment significantly increased ESP over the control, increasing the mean value from 1.0 to $1.5 \%$. Cow slurry had a pronounced effect on ESP, the increase being directly proportional to the application rate (Figure 3 ).

Increased ESP has been related to decreased soil hydraulic conductivity and infiltration rate (Frenkel et al. 1978; Sumner 1993; Halliwell et al. 2001). The mechanism by which this may occur is by damaging soil structure (Halliwell et al. 2001; Collis-George 2003; Quirk 2003). The increased prevalence of $\mathrm{Na}^{+}$in exchange for divalent cations increases electrostatic repulsion between soil particles. In terms of the Guoy-Chapman diffuse double layer theory, an increase in the prevalence of monovalent cations will increase the size of the double layer, as it is inversely proportional to the square of the valency of the neutralizing cation. This aids clay dispersion, which damages soil structure by breaking up tactoids and can lead to surface sealing.

Threshold values of $5-15 \%$ ESP have been given for the definition of a sodic soil, but these thresholds are somewhat arbitrary and the detrimental physical effects of increased ESP act over a continuum of values, so that soils with lower ESP can exhibit sodic behaviour (So \& Aylmore 1993; Sumner 1993; Halliwell et al. 2001). There is no generally accepted definition of a sodic soil (Sumner 1993). Lebron et al. (2002) found that hydraulic conductivity decreased sharply as ESP approached 5\%. An ESP of only $2.2 \%$ can cause a $70 \%$ decrease in infiltration rate (Shainberg \& Letey 1984). Soils with a high clay or silt content might be expected to be more sensitive to increased ESP than sandy soils.

The HC treatment resulted in soils with $>5 \%$ ESP over all depths, and this might be expected to influence soil physical conditions, decreasing infiltration rate. Decreased 
Table 1. The effect of treatment on exchangeable sodium percentage (ESP), exchangeable cations and cation exchange capacity (CEC), Olsen $\mathrm{P}$ and pH, including levels of probability.

\begin{tabular}{|c|c|c|c|c|c|c|c|c|c|}
\hline \multirow[t]{2}{*}{ Treatment $^{\mathrm{a}}$} & Depth $(\mathrm{cm})$ & ESP (\%) & $\mathrm{Na}^{+}$ & $\mathrm{K}^{+}$ & $\mathrm{Mg}^{2+}$ & $\mathrm{Ca}^{2+}$ & CEC & \multirow[t]{2}{*}{ Olsen $\mathrm{P}^{\mathrm{b}}\left(\mathrm{mg} \mathrm{L}^{-1}\right)$} & \multirow[t]{2}{*}{$\mathrm{pH}$} \\
\hline & \multicolumn{7}{|c|}{$\left(\mathrm{cmol}_{\mathrm{c}} \mathrm{kg}^{-1}\right)$} & & \\
\hline \multirow[t]{3}{*}{ CTRL } & $0-5$ & 1.18 & 0.32 & 0.34 & 0.68 & 12.42 & 27.06 & 14.00 & 6.09 \\
\hline & $5-10$ & 0.86 & 0.18 & 0.16 & 0.37 & 10.11 & 21.71 & 8.33 & 6.28 \\
\hline & $10-15$ & 0.83 & 0.16 & 0.15 & 0.31 & 9.34 & 19.77 & 8.00 & 6.32 \\
\hline \multirow[t]{3}{*}{ NPK } & $0-5$ & 1.28 & 0.33 & 0.44 & 0.32 & 12.57 & 25.71 & 44.33 & 6.09 \\
\hline & $5-10$ & 0.90 & 0.19 & 0.19 & 0.06 & 11.69 & 21.79 & 19.83 & 6.29 \\
\hline & $10-15$ & 0.91 & 0.19 & 0.17 & 0.42 & 10.45 & 21.10 & 34.83 & 6.31 \\
\hline \multirow[t]{3}{*}{ LP } & $0-5$ & 1.22 & 0.32 & 0.33 & 1.38 & 13.01 & 26.53 & 52.33 & 6.04 \\
\hline & $5-10$ & 0.96 & 0.22 & 0.16 & 0.84 & 11.94 & 23.14 & 26.67 & 6.25 \\
\hline & $10-15$ & 0.87 & 0.17 & 0.13 & 0.61 & 10.44 & 20.19 & 17.50 & 6.33 \\
\hline \multirow[t]{3}{*}{ MP } & $0-5$ & 1.13 & 0.31 & 0.29 & 1.92 & 13.17 & 27.51 & 100.67 & 6.26 \\
\hline & $5-10$ & 0.91 & 0.22 & 0.16 & 1.32 & 12.07 & 25.00 & 69.00 & 6.42 \\
\hline & $10-15$ & 0.94 & 0.21 & 0.15 & 0.98 & 10.60 & 21.93 & 51.00 & 6.46 \\
\hline \multirow[t]{3}{*}{ HP } & $0-5$ & 1.75 & 0.55 & 0.84 & 2.77 & 13.23 & 31.84 & 202.50 & 6.14 \\
\hline & $5-10$ & 1.42 & 0.38 & 0.45 & 2.09 & 12.00 & 26.87 & 192.50 & 6.24 \\
\hline & $10-15$ & 1.21 & 0.28 & 0.26 & 1.56 & 9.61 & 23.18 & 145.83 & 6.24 \\
\hline \multirow[t]{3}{*}{ LC } & $0-5$ & 2.58 & 0.65 & 1.03 & 1.84 & 10.97 & 25.72 & 27.50 & 6.11 \\
\hline & $5-10$ & 1.84 & 0.42 & 0.63 & 1.16 & 9.49 & 23.05 & 12.33 & 6.23 \\
\hline & $10-15$ & 1.59 & 0.31 & 0.45 & 0.86 & 8.68 & 19.53 & 9.33 & 6.28 \\
\hline \multirow[t]{3}{*}{ MC } & $0-5$ & 3.82 & 1.07 & 2.05 & 3.24 & 9.97 & 28.08 & 60.33 & 6.18 \\
\hline & $5-10$ & 4.24 & 1.00 & 1.73 & 2.25 & 8.32 & 23.57 & 27.67 & 6.37 \\
\hline & $10-15$ & 3.90 & 0.80 & 1.33 & 1.61 & 7.35 & 20.74 & 17.67 & 6.37 \\
\hline \multirow[t]{3}{*}{$\mathrm{HC}$} & $0-5$ & 5.60 & 1.66 & 3.13 & 4.06 & 10.77 & 29.98 & 138.33 & 6.35 \\
\hline & $5-10$ & 5.78 & 1.55 & 2.91 & 3.22 & 9.36 & 27.16 & 89.83 & 6.59 \\
\hline & $10-15$ & 6.29 & 1.48 & 2.67 & 2.57 & 8.08 & 23.65 & 61.00 & 6.59 \\
\hline \multicolumn{2}{|l|}{$\begin{array}{l}\text { LSD } \\
\text { Comparison }\end{array}$} & 0.464 & 0.102 & 0.206 & 0.251 & 1.524 & 1.907 & & 0.188 \\
\hline \multicolumn{2}{|l|}{ Treatment $^{\mathrm{c}}$} & $<0.001$ & $<0.001$ & $<0.001$ & $<0.001$ & 0.021 & $<0.001$ & $<0.001$ & 0.430 \\
\hline \multicolumn{2}{|c|}{ Slurry type ${ }^{\mathrm{d}}$} & $<0.001$ & $<0.001$ & $<0.001$ & 0.504 & 0.132 & 0.347 & $<0.002$ & 0.152 \\
\hline \multicolumn{2}{|c|}{ Slurry application rate } & $<0.001$ & $<0.001$ & $<0.001$ & $<0.001$ & 0.112 & $<0.001$ & $<0.003$ & 0.048 \\
\hline \multicolumn{2}{|c|}{ Slurry type $\times$ rate } & $<0.001$ & $<0.001$ & $<0.001$ & $<0.001$ & $<0.001$ & 0.002 & 0.450 & 0.015 \\
\hline \multicolumn{2}{|c|}{ Soil depth } & 0.002 & $<0.001$ & $<0.001$ & $<0.001$ & $<0.001$ & $<0.001$ & $<0.001$ & $<0.001$ \\
\hline \multicolumn{2}{|c|}{ Treatment $\times$ depth } & $<0.001$ & 0.231 & 0.180 & $<0.001$ & 0.764 & 0.224 & 0.040 & 0.755 \\
\hline \multicolumn{2}{|c|}{ Slurry type $\times$ depth } & 0.009 & 0.034 & 0.098 & 0.999 & 0.433 & 0.685 & 0.016 & 0.672 \\
\hline \multicolumn{2}{|c|}{ Slurry rate $\times$ depth } & 0.077 & 0.021 & $<0.001$ & 0.001 & 0.615 & 0.226 & 0.007 & 0.449 \\
\hline \multicolumn{2}{|c|}{ Slurry type $\times$ rate $\times$ depth } & 0.120 & 0.009 & 0.002 & 0.259 & 0.214 & 0.775 & 0.273 & 0.023 \\
\hline
\end{tabular}

${ }^{\mathrm{a}}$ For treatment key, see Materials and Methods; ${ }^{\mathrm{b}}$ Olsen $\mathrm{P}$ values were transformed to logê values and analysed; ${ }^{\mathrm{c}}$ treatment $=$ fertilizer vs control vs slurry; $\mathrm{d}_{\text {slurry type }}=\mathrm{cow}$ vs pig. $\mathrm{LSD}=$ least significant difference.

infiltration rate may increase overland flow from soils, which has been identified as an important $\mathrm{P}$ loss pathway (Haygarth \& Jarvis 1999; Heathwaite \& Dils 2000). The hydrological properties of the soil surface are particularly sensitive to increases in ESP due to the low electrolyte concentration of the infiltrating water, the energy of raindrop impact, and the lack of a surrounding soil matrix (Agassi et al. 1981; Sumner 1993). Surface hydrology is critical in determining the distribution of water between subsurface and overland flow. Thus, the fact that treatment effects were concentrated at the surface gives further cause for concern.

Levels of ESP tended to decrease with depth for all treatments except the MC and HC, for which the trend was reversed. This decrease with depth reflects the concentration of $\mathrm{Na}^{+}$at the surface due to surface application of slurries. However, the increase in ESP with depth for the two highest rates of cow slurry suggests an increased mobility of $\mathrm{Na}^{+}$in the soil profile at higher rates of application. $\mathrm{Na}^{+}$leached to lower depths in the profile will exchange from solution to the solid phase. The effect of this exchanged $\mathrm{Na}^{+}$on ESP may be more marked at depth, due to a smaller CEC than at the surface.

The effects of increased ESP on soil hydrology have been found to be magnified by raised soil $\mathrm{pH}$ (Suarez et al. 1984), which will tend to increase the negative charge on variable charge surfaces (Frenkel et al. 1978; Sumner 1993). This gives further cause for concern with soils receiving cow slurry (Table 1).

It should be noted that long-term slurry application will also increase humified SOM at the soil surface, increasing aggregate stability. This might counter the effects of 


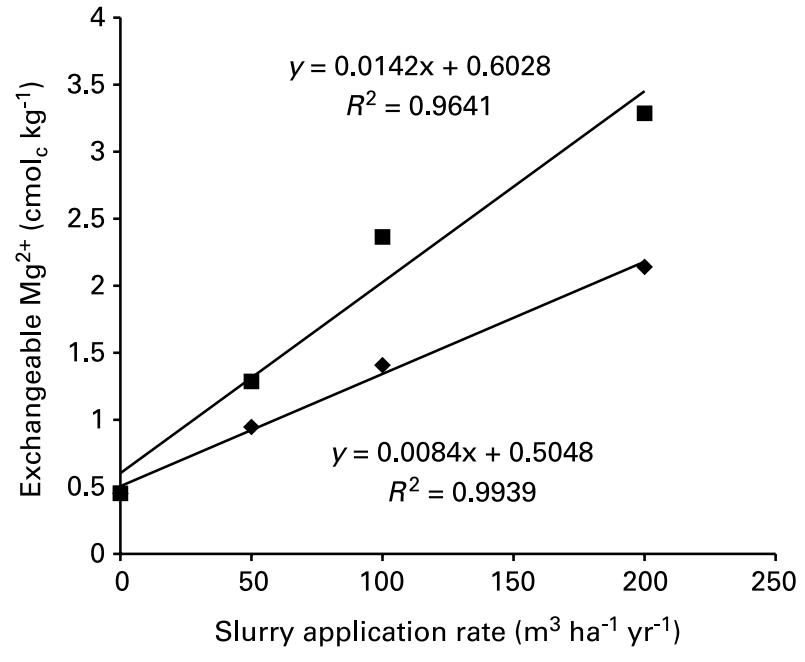

Figure 1. The effect of slurry application rate on exchangeable $\mathrm{Mg}^{2+}$ averaged over $0-15 \mathrm{~cm}$ soil depth for pig $(\diamond)$ and cow $(\square)$ slurries.

changed cation balance on aggregate stability. Therefore, the effect of slurry application on soil structure and hydrology may depend on a balance between these processes.

In addition to physical effects, the capacity of the soil to sorb $\mathrm{P}$ anions may be decreased by the increased proportion of monovalent cations on the exchange sites (Curtin et al. 1987; Smillie et al. 1987). If slurry alters soil infiltration rate because of its $\mathrm{Na}^{+}$content, the environmental impact could be exacerbated because of concomitant soil $\mathrm{P}$ accumulation. $P$ accumulated, particularly at $0-5 \mathrm{~cm}$ depth in the cow slurry treatments, to levels well beyond the agronomic optimum of $16-25 \mathrm{mg} \mathrm{L}^{-1}$ (MAFF 2000) (Figure 4). The greatest potential risk from a combination of soil physical and chemical effects is on the MC and HC treatments. It may be necessary to consider long-term strategies of controlled application to avoid such detrimental effects.

The application of lime is the usual practice in Ireland to raise soil $\mathrm{pH}$ and counter $\mathrm{Al}$ toxicity. It is necessary to

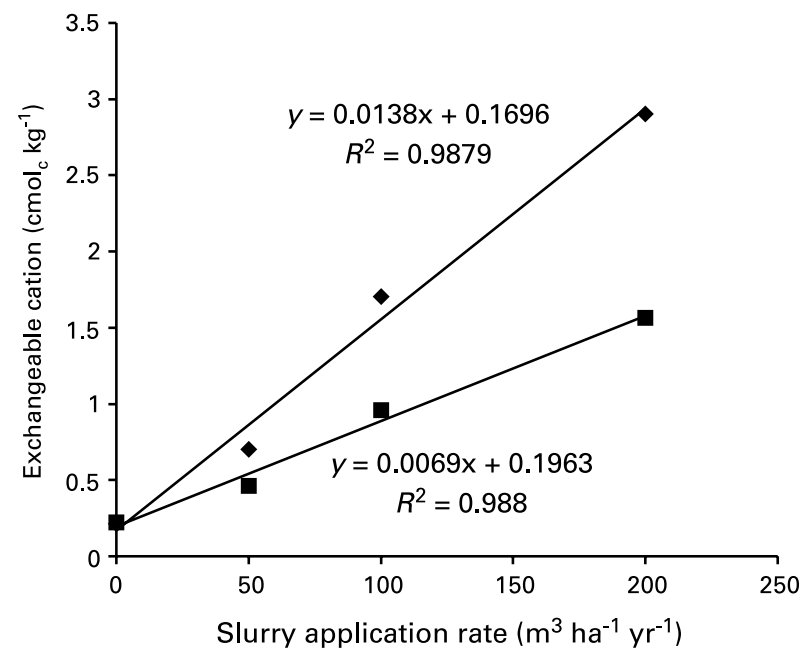

Figure 2. The effect of cow slurry application rate on exchangeable $\mathrm{K}^{+}(\diamond)$ and $\mathrm{Na}^{+}(\boldsymbol{\square})$ averaged over $0-15 \mathrm{~cm}$ soil depth.

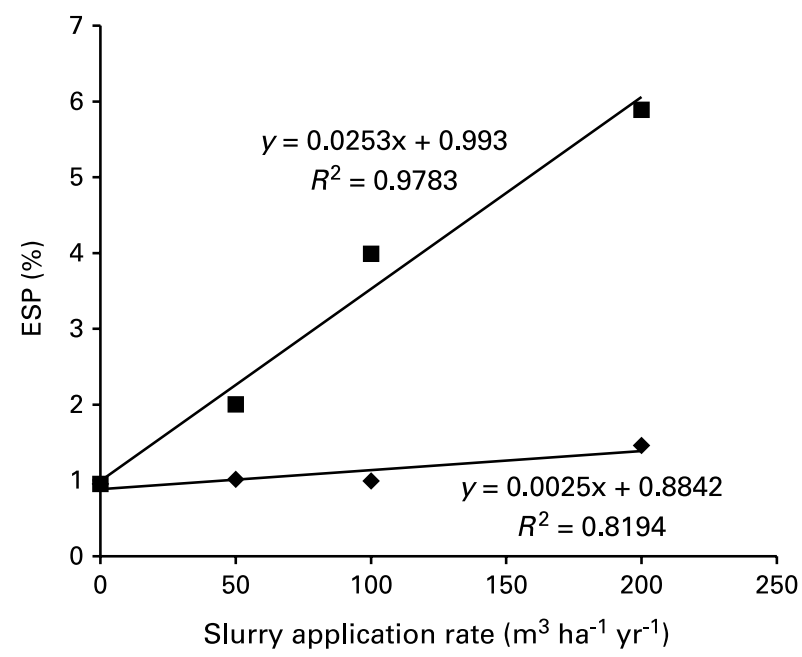

Figure 3. The effect of slurry application rate on exchangeable sodium percentage (ESP) averaged over $0-15 \mathrm{~cm}$ depth for pig $(\diamond)$ and cow ( $\square$ ) slurries.

counteract the process of acidification, which is prevalent under Irish climatic conditions. However, soil $\mathrm{pH}$ is already greater than 6.0 in the HC treatment without lime having been applied at any time over the 32 years to all but one of the HC plots; thus the addition of lime to supply $\mathrm{Ca}^{2+}$ and increase soil $\mathrm{pH}$ further is not an agronomic option. The addition of gypsum is a possible management strategy to minimize the impact of slurry (Shainberg \& Letey 1984; Halliwell et al. 2001; Lebron et al. 2002). Gypsum can provide the $\mathrm{Ca}^{2+}$ needed to exchange for $\mathrm{Na}^{+}$and $\mathrm{K}^{+}$and maintain a higher electrolyte concentration in solution; it has been shown to improve soil physical conditions (Shainberg \& Letey 1984; Sumner 1993; Yu et al. 2003) and $P$ retention (Vidal et al. 2003).

\section{CONCLUSIONS}

Long-term applications of pig and cow slurries increased ESP, exchangeable $\mathrm{Na}^{+}, \mathrm{K}^{+}$and $\mathrm{Mg}^{2+}, \mathrm{CEC}, \mathrm{pH}$ and

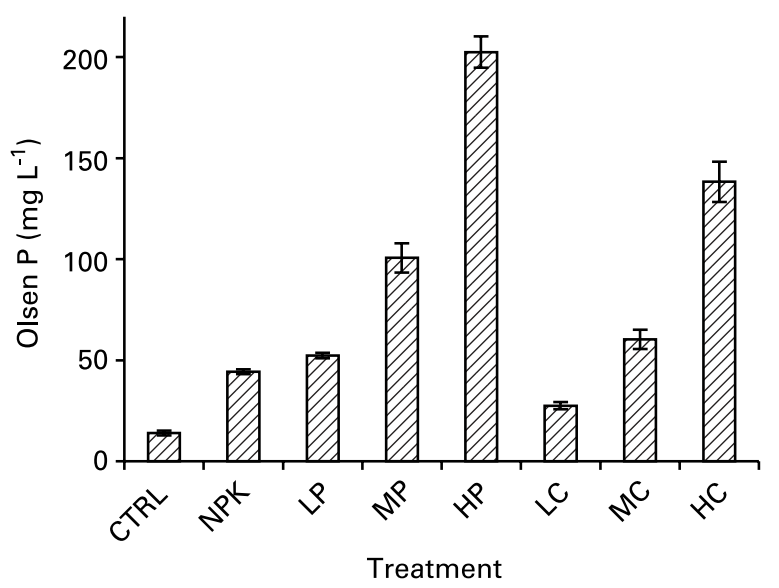

Figure 4. The effect of various slurry treatments on Olsen P over $0-5 \mathrm{~cm}$ soil depth. For treatment key, see Materials and Methods. 
Olsen P. These effects were particularly marked for cow slurry. Treatment effects tended to be concentrated in the upper $5 \mathrm{~cm}$ of the soil horizon. The physical and chemical effects of increased ESP with a concurrent increase in soil $\mathrm{P}$ gives cause for concern with regard to $\mathrm{P}$ loss to surface waters from agricultural soils receiving slurry, particularly in the case of cow slurry. The effect of slurry application increased with application rate and it may be necessary to consider long-term strategies of controlled application to avoid detrimental effects. Lime or gypsum may be applied as a possible ameliorant, depending on soil $\mathrm{pH}$.

\section{ACKNOWLEDGEMENTS}

The authors would like to acknowledge the help of Michael Nicholson with sample analysis and Erica Chisholm with statistical analysis. This work was carried out as part of a $\mathrm{PhD}$ project funded by the Thomas Henry Foundation.

\section{REFERENCES}

Agassi M Shainberg I \& Morin J 1981. Effect of electrolyte concentration and soil sodicity on infiltration rate and crust formation. Soil Science Society of America Journal 45, 848-851.

Anderson R \& Wu Y 2001. Phosphorus quantity-intensity relationships and agronomic measures of $\mathrm{P}$ in surface layers of soil from a long-term slurry experiment. Chemosphere 42, 161-170.

Avery BW \& Bascomb CL 1974. Soil Survey Technical Monograph No. 6. Soil survey laboratory methods. Adlard \& Son Ltd Dorking UK.

Boorman DB Hollis JM \& Lilly A 1995. Hydrology of soil types: a hydrologically-based classification of the soils of the United Kingdom. Report no. 126 Institute of Hydrology Wallingford UK.

Christie P 1987. Some long-term effects of slurry on grassland. Journal of Agricultural Science Cambridge 108, 529-541.

Collis-George N 2003. Reply to comments on 'The application of doublelayer theory to drainage, drying and wetting, and the Gapon Exchange constant in a soil with mono- and divalent cations', by JP Quirk. European Journal of Soil Science 54, 213-214.

Curtin D Syers JK \& Smillie GW 1987. The importance of exchangeable cations and resin sink characteristics in the release of soil phosphorus. Journal of Soil Science 38, 711-716.

Foy RH Smith RV Jordan C \& Lennox SD 1995. Upward trend in soluble phosphorus loadings to Lough Neagh despite phosphorus reduction at sewage treatment works. Water Research 29, 1051-1063.

Frenkel H Goertzen JO \& Rhoades JD 1978. Effects of clay type and content, exchangeable sodium percentage, and electrolyte concentration on clay dispersion and soil hydraulic conductivity. Soil Science Society of America Journal 41, 32-39.

Halliwell DJ Barlow KM \& Nash DM 2001. A review of the effects of wastewater sodium on soil physical properties and their implications for irrigation systems. Australian Journal of Soil Research 39, 1259-1267.

Hao X \& Chang C 2002. Effect of 25 annual cattle manure applications on soluble and exchangeable cations in soil. Soil Science 167, 126-134.
Haygarth PM \& Jarvis SC 1999. Transfer of phosphorus from agricultural soils. Advances in Agronomy 66, 195-249.

Haynes RJ \& Naidu R 1998. Influence of lime, fertiliser and manure applications on soil organic matter content and soil physical conditions: a review. Nutrient Cycling in Agroecosystems 51, 123-137.

Heaney SI Foy RH Kennedy GJA Crozier WW \& O’Connor WCK 2001. Impacts of agriculture on aquatic systems: lessons learnt and new unknowns in Northern Ireland. Marine and Freshwater Research 52, $151-163$.

Heathwaite AL \& Dils RM 2000. Characterising phosphorus loss in surface and subsurface hydrological pathways. The Science of the Total Environment 251/252, 523-538.

Lebron I Suarez DL \& Yoshida T 2002. Gypsum effect on the aggregate size and geometry of three sodic soils under reclamation. Soil Science Society of America Journal 66, 92-98.

MAFF 1986. The analysis of agricultural materials. HMSO Norwich UK.

MAFF 2000. Fertiliser recommendations for agricultural and horticultural crops (RB 209). HMSO Norwich UK.

McGechan MB 2001. Modelling through soil losses of phosphorus to surface waters. American Society of Agricultural Engineers Meeting Paper No. 01-2011. ASAE St Josepa MI.

Olsen SR Cole CV Watanabe ES \& Deane LA 1957. Estimation of available phosphorus in soils by extraction with sodium bicarbonate. US Department of Agriculture Circular No. 939 Washington DC.

Quirk JP 2003. Comments on 'The application of double-layer theory to drainage, drying and wetting, and the Gapon Exchange constant in a soil with mono- and divalent cations', by N. Collis-George. European Journal of Soil Science 54, 211-213.

Shainberg I \& Letey J 1984. Response of soils to sodic and saline conditions. Hilgardia 52, 1-57.

Shaviv A Jury WA \& Pratt PF 1986. Exchange, fixation and precipitation of cations during leaching of soils amended with manure: 1. Column experiments. Soil Science 141, 237-242.

Smillie GW Curtin D \& Syers JK 1987. Influence of exchangeable calcium on phosphate retention by weakly acid soils. Soil Science Society of America Journal 51, 1169-1172.

So HB \& Aylmore AG 1993. How do sodic soils behave? The effects of sodicity on soil physical behaviour. Australian Journal of Soil Research 31, 761-777.

Suarez DL Rhoades JD Lavado R \& Grieve CM 1984. Effect of $\mathrm{pH}$ on saturated hydraulic conductivity and soil dispersion. Soil Science Society of America Journal 48, 50-55.

Sumner ME 1993. Sodic soils: new perspectives. Australian Journal of Soil Research 31, 683-750.

Van Vliet LJP Zebarth BJ \& Derksen G 2002. Effect of fall-applied manure practices on runoff, sediment, and nutrient surface transport from silage corn in south coastal British Columbia. Canadian Journal of Soil Science $82,445-456$.

Vidal M Lopez A Espejo R \& Blazquez R 2003. Comparative analysis of corrective action of various liming and gypsum amendments on a palexerult. Communications in Soil Science and Plant Analysis 34, 709-723.

Yu J Lei T Shainberg I Mamedov AI \& Levy GJ 2003. Infiltration and erosion in soils treated with dry PAM and gypsum. Soil Science Society of America Journal 67, 630-636.

Received September 2004, accepted after revision February 2005. 